\title{
Urban Development and Stream Ecosystem Health—Science Capabilities of the U.S. Geological Survey
}

Urban development creates multiple stressors that can degrade stream ecosystems by changing stream hydrology, water quality, and physical habitat. Contaminants, habitat destruction, and increasing streamflow variability resulting from urban development have been associated with the disruption of biological communities, particularly the loss of sensitive aquatic biota. Understanding how algal, invertebrate, and fish communities respond to these physical and chemical stressors can provide important clues as to how streams should be managed to protect stream ecosystems as a watershed becomes increasingly urbanized. The U.S. Geological Survey (USGS) continues to lead monitoring efforts and scientific studies on the effects of urban development on stream ecosystems in metropolitan areas across the United States.

\section{Expertise and Resources}

The USGS scientists of the Northeast Region Urban Landscapes Capability Team share expertise and resources to provide and interpret data on a wide range of urban-related issues at local, regional, and national levels. Data collected from traditional water and bed-sediment samples are complemented with ecological toxicity and bioassay analyses to assess the exposure and vulnerability of organisms living in stream water and bed sediments. The ecological condition of streams and lakes are assessed by surveying fish, invertebrate, and algal communities and by analyzing biological tissues for contaminants.

\section{Streamflow Variability and Loss of Sensitive Species}

Natural fluctuations of flows are critical to stream health because they build and maintain physical habitats, influence physical and chemical characteristics of water, and provide important life-stage cues for aquatic organisms. Urban development typically modifies streams by altering the magnitude, duration, frequency, and timing of streamflow. As the percentage of impervious surfaces and levels of stormwatermanagement controls increase with urban development, the amount of runoff entering streams frequently results in higher flows that can alter stream habitat from channel erosion. Additionally, rapid runoff reduces soil infiltration and aquifer recharge, which often results in lower sustained streamflows during summer. These changes generally result in a shift in the species composition of the biological communities, specifically with losses of fish species diversity and sensitive invertebrate species. As a result, the biological community shifts to a higher percentage of species more tolerant to physical and chemical stressors. Understanding how stream ecosystems change with increasing urban development can assist in the development of protective and rehabilitative management actions. Results from USGS studies (http://water.usgs.gov/nawqa/urban/html/publications.html) document the pervasiveness and severity of streamflow modification across the Nation and provide water-resources managers with regional-scale perspectives on the importance of maintaining natural streamflow to preserve biological communities and stream health.

\section{Chemical Stressors and Ecosystem Health}

Urban development may increase the inputs to streams of complex chemical mixtures typically present in runoff from impervious surfaces in industrial and suburban areas. These mixtures may include pesticides, nutrients, chloride, metals, organic wastewater compounds, and other chemicals that have deleterious biological effects. These effects of toxicity on the biological communities may be defined in terms of

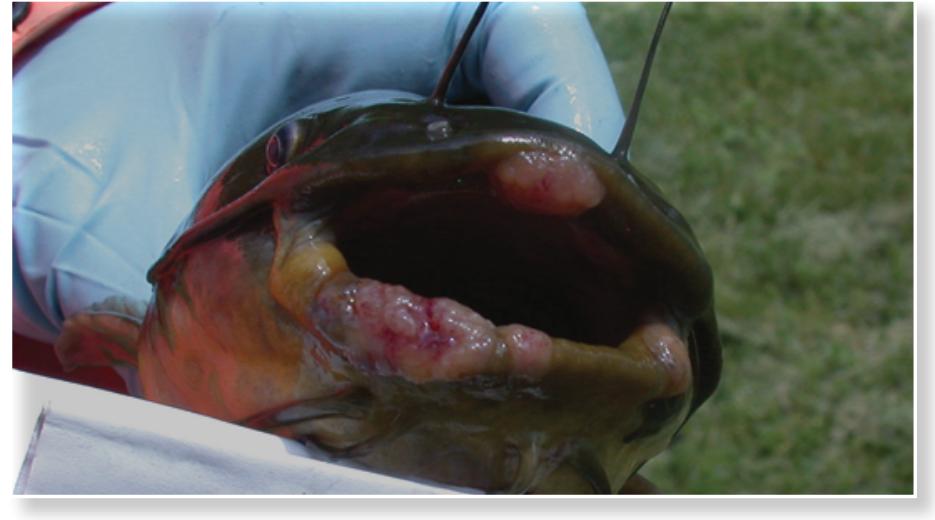

Photograph of a brown bullhead (Ameiurus nebulosis) with lip tumors that was collected from the Presque Isle Bay Area of Concern in Erie, Pennsylvania. Bullhead species dwell and feed near bottom sediments; therefore, they are often used as an indicator species of environmental health (Blazer and others, 2014). Photograph by Vicki Blazer, U.S. Geological Survey.

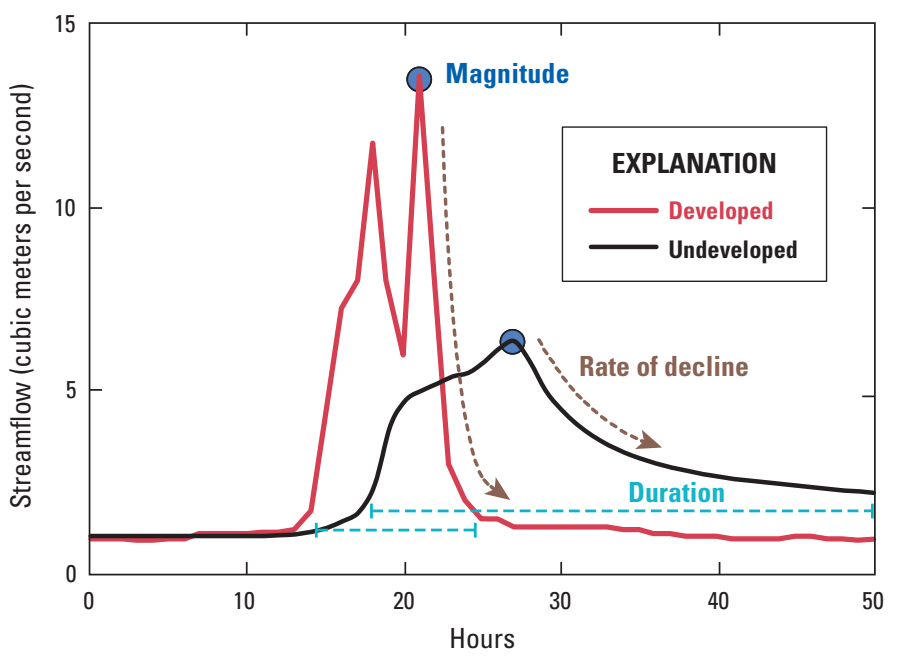

A common effect of urbanization on stream hydrology is that the frequency and magnitude of high flows generally increase and flow durations generally decrease as a result of rapid runoff from impervious surfaces. Figure from Coles and others (2012). 
limited survival, growth, and reproduction. Minor amounts of some compounds commonly present in urban streams may have immediate or long-term effects on ecosystem community structure, diversity, and productivity. For example, endocrine disruption (U.S. Geological Survey, 2009) and reproductive effects have been documented for fish (Blazer and others, 2013) from contaminants of emerging concern such as hormones, estrogenic pesticides (U.S. Geological Survey, 2012), and wastewater compounds. The bioaccumulation of trace elements, such as mercury, has been indicated to have reproductive and behavioral effects on fish and their higher level predators. Large increases in stream chloride concentrations in watersheds with increased urban development have been observed throughout the Northeastern United States where road salt and deicing chemicals are used extensively and may affect the survival of sensitive aquatic species.

In urban environments, increased stormwater runoff can introduce contaminants to the streams and alter streambed sediment chemistry and, thereby, increase the associated toxicity to biological communities. Flushing of urban streams during flood events can then resuspend and redistribute these contaminated sediments along the streambed and into downstream estuaries. The USGS stream assessment capabilities include identifying the presence of specific contaminants in water, sediment, and biological tissue, and evaluating ecosystem health by testing ecological toxicity.

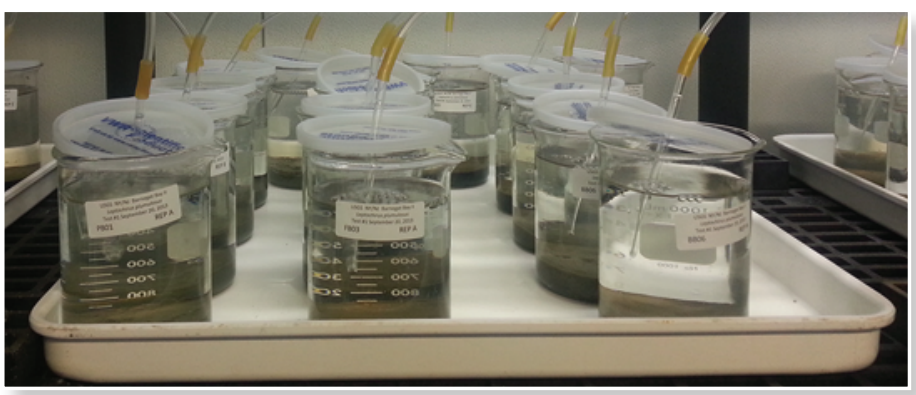

Ecological toxicity tests provide data on the lethal and sublethal (reproductive, developmental, and behavior) effects of the chemical composition of the bed-sediment samples to which the organisms are exposed. Photograph by Jacob K. Stanley, U.S. Army Corps of Engineers.

\section{Examples of USGS Urban Ecology Studies USGS National Water Census}

Tributaries in the Delaware River Basin are currently [2016] being studied to define relations that exist among major components of streamflow (magnitude, durations, frequency, timing, and rate of change) and the response of aquatic biological communities. This information will assist managers in making decisions about meeting human water needs while maintaining a healthy stream. http://water.usgs.gov/watercensus/delaware.html

\section{Northeast Region Stream Quality Assessment}

The goal of the Northeast Stream Quality Assessment study is to assess the quality of streams in the region by characterizing multiple water-quality factors that are stressors to aquatic life and evaluating the relation among these stressors and biological communities. The Northeast Stream Quality Assessment will focus on the effects of urbanization and agriculture on stream quality in New England, New York, and the northernmost parts of New Jersey and Pennsylvania. http://txpub.usgs.gov/RSQA/

\section{USGS Environmental Health Program}

Contaminants of emerging concern can have natural or synthetic sources that are present in the environment but are not commonly monitored. The USGS has ongoing environmental health research in the Northeast Region and nationally on these contaminants because these chemical compounds have the potential to cause adverse ecological or human health effects, or both. The primary goals of the research program are to develop analytical methods to detect these contaminants at low concentrations and to provide information on the frequency of detection, sources, transport and fate, and ecological effects of a variety of emerging contaminants. http://toxics.usgs.gov/regional/emc/index.html

\section{USGS Regional Studies on the Effects of Urbanization on Stream Ecosystems}

As part of the USGS National Water Quality Assessment, researchers studied the relation between varying levels of urban intensity and stream water quality, as measured by physical, chemical, and biological factors in 11 metropolitan areas. For these studies, stream water quality was considered a composite of physical, chemical, and biological characteristics influenced by natural factors and by human activities. Biological communities reflect the integration of these influences. http:/water.usgs.gov/nawqa/urban/index.html

\section{Partnering Opportunities}

The USGS is a leader in monitoring the effects of urban development and land-use change on stream ecosystems. Ecosystem studies led by the USGS use standardized protocols and analytical procedures to integrate data from multiple biological communities so that assessments of stream health and its relation to urbanization can be compared nationally and locally. Access to USGS expertise is possible through numerous partnering opportunities. State and local agencies may partner with the USGS and access matching funds through the Cooperative Water Program (http://water.usgs.gov/coop/). Federal agencies, educational institutions, nonprofit organizations, and other entities may partner with the USGS through a variety of programs.

\section{References Cited}

Blazer, V.S., Mazik, P.M., Iwanowicz, L.R., Braham, R.P., Hahn, C.M., Walsh H.L., and Sperry, A.J., 2014, Assessment of the fish tumor beneficial use impairment in brown bullhead (Ameiurus nebulosus) at selected Great Lakes areas of concern: U.S. Geological Survey Open-File Report 2014-1105, 17 p., accessed April 12, 2016, at http://dx.doi.org/10.3133/ofr20141105.

Blazer, V.S., Pinkney, A.E., Jenkins, J.A., Iwanowicz, L.R., Minkkinen, Steven, Draugelis-Dale, R.O., and Uphoff, J.H., 2013, Reproductive health of yellow perch Perca flavescens in selected tributaries of the Chesapeake Bay: Science of the Total Environment, v. 447, p. 198-209, accessed April 12, 2016, at http://www.sciencedirect.com/science/article/pii/S0048969712016452.

Coles, J.F., McMahon, Gerard, Bell, A.H., Brown, L.R., Fitzpatrick, F.A., Scudder Eikenberry, B.C., Woodside, M.D., Cuffney, T.F., Bryant, W.L., Cappiella, Karen, Fraley-McNeal, Lisa, and Stack, W.P., 2012, Effects of urban development on stream ecosystems in nine metropolitan study areas across the United States: U.S. Geological Survey Circular 1373, 138 p., accessed April 12, 2016, at http://pubs.usgs.gov/circ/1373/.

U.S. Geological Survey, 2009, Tackling fish endocrine disruption: U.S. Geological Survey Environmental Health Web page, accessed April 12, 2016, at http://toxics.usgs.gov/highlights/fish_endocrine_disruption.html.

U.S. Geological Survey, 2012, Pyrethroid insecticide contamination of streams increases with urbanization: U.S. Geological Survey Environmental Health Web page, accessed April 12, 2016, at http://toxics.usgs.gov/highlights/pyrethroids_in_streams.html.

\section{By Pamela A. Reilly, Zoltan Szabo, and James F. Coles}

\section{For more information about these USGS projects and about partnering opportunities, contact:}

USGS Northeast Region Urban Landscapes Capability Team

Email: GS-NE_ULCT@usgs.gov

or contact your local USGS office

https://www.usgs.gov/contact_us 